\title{
PRAKTIK MEDIASI PADA BADAN PENASEHATAN PEMBINAAN DAN PELESTARIAN PERKAWINAN DI KABUPATEN MINAHASA UTARA
}

\author{
Noval Besse \\ Kementerian Agama Kabupaten Minahasa Utara \\ noval.besse@gmail.com
}

\begin{abstract}
The construction of the construction and preservation of marriage (bp4) is the means that countries present to resolve the problems in the homes leading to divorce in the community, including the north minahasa district. Amazingly, in those areas the entire family's marital problems could be solved and avoided divorce. Thus, the focus of this article is on how the practice of mediation by the bp 4 in the district of minahasa north in complete marital strife. The result is that the bp 4 in the north minhasa district used several applied methods, namely; Informative methods, which provide light or information; The method of suggestion and persuasion is how to influence clients to be willing to follow the advice given; Edukative method, that is, a way of educating advice; The method of discussion, which refers to solving problems by explaining the problems that clients face; And a method of speech to soothe their hearts. By applying those methods, the whole mediation can be effective and successful.
\end{abstract}

Keywords: The Practice of Mediation, the Efficacy of Mediation, BP4, The Region of North Minahasa.

\begin{abstract}
Abstrak. Badan Penasehatan Pembinaan dan Pelestarian Perkawinan (BP4) adalah sarana yang dihadirkan oleh Negara untuk menyelesaikan problem-problem dalam rumahtangga yang berujung pada perceraian di masyarakat, termasuk di Kabupaten Minahasa Utara. Hebatnya, di Kabupaten tersebut seluruh permasalahan keluarga yang akan bercerai dapat diselesaikan dan terhindar dari perceraian. Oleh karenanya, fokus artikel ini adalah pada bagaimana praktik mediasi oleh BP4 di Kabupaten Minahasa Utara dalam menyelesaikan perselisihan rumah tangga pasca nikah. Hasilnya adalah, bahwa BP4 di Kabupaten Minhasa Utara menggunakan beberapa metode terapan, yakni; metode informatif, yang bersifat memberikan penerangan atau informasi; metode sugesti dan persuasif, yaitu cara mempengaruhi klien agar bersedia mengikuti nasehat yang diberikan; metode edukatif, yaitu cara pemberian nasehat yang bersifat mendidik; metode diskusi, yaitu mengarah pada pemecahan masalah dengan menjelaskan problem yang dihadapi klien; dan metode ceramah untuk menenangkan hati mereka. Walhasil dengan menerapkan metode-metode tersebut, seluruh mediasi dapat berjalan dengan efektif dan sukses.
\end{abstract}

Kata Kunci: Praktik Mediasi, Efektivitas Mediasi, BP4, Kabupaten Minahasa Utara 


\section{Pendahuluan}

Perkawinan merupakan suatu hal yang penting dalam realita kehidupan umat manusia. Perkawinan adalah salah satu sunnatullah yang umum berlaku pada semua makhluk Tuhan, baik pada manusia, hewan, maupun tumbuhtumbuhan. Jadi, perkawinan secara umum bisa dilakukan semua makhluk hidup. ${ }^{1}$

Perkawinan merupakan salah satu perintah agama kepada yang mampu untuk segera melaksanakannya. Karena perkawinan dapat mengurangi kemaksiatan, baik dalam bentuk penglihatan maupun dalam bentuk perzinahan. Orang yang berkeinginan untuk melakukan pernikahan, tetapi belum mempunyai persiapan bekal (fisik dan nonfisik) dianjurkan oleh Nabi Muhammad saw, untuk berpuasa. Orang berpuasa akan memiliki kekuatan atau penghalang dari berbuat tercela yang sangat keji, yaitu perzinahan. ${ }^{2}$

Oleh karena itu, sangat tepat bila Islam mengatur masalah perkawinan dengan terperinci, untuk membawa manusia hidup berkehormatan, sesuai kedudukannya yang amat mulia di tengah-tengah makhluk Allah yang lain. Hubungan antara laki-laki dan perempuan khususnya dalam bidang perkawinan sudah diatur dalam alQur'an maupun as-Sunnah. Hukum perkawinan mempunyai kedudukan penting dalam Islam, sebab hukum perkawinan mengatur tata cara kehidupan keluarga yang merupakan inti kehidupan masyarakat. ${ }^{3}$

\footnotetext{
1 Chuzaemah T. Yanggo dan Hafiz Anshari, Problematika Hukum Islam Kontemporer (Cet. IV, Jakarta: Pustaka Firdaus, 2002), h. 56.

2 Zainuddin Ali, Hukum Perdata Islam di Indonesia (Jakarta: Sinar Grafika, 2006), h. 7.

${ }^{3}$ Ahmad Azhar Basir, Hukum Perkawinan Islam (Yogyakarta: UII Press, 2007), h. 1-2.
}

Bahkan Islam mengajarkan agar suami jangan tergesa-gesa untuk menjatuhkan talak ketika ada konflik, akan tetapi terlebih dahulu dilakukan proses mediasi. ${ }^{4}$ Dalam Al-Qur'an tidak ada ayat yang menerangkan untuk bercerai ketika terjadi konflik dalam rumah tangga itu karena perceraian sangat dibenci oleh Allah swt, melainkan memberi jalan keluar dengan proses mediasi. ${ }^{5}$ Islam juga mengenal adanya tahkim, yakni berlindungya dua pihak yang bersengketa kepada orang lain yang mereka sepakati dan disetujui serta rela menerima keputusan untuk menyelesaikan persengketaan mereka. ${ }^{6}$

Di Indonesia, proses mediasi selain difasilitasi oleh Mahkamah Agung juga difasilitasi oleh BP4, dan sejak BP4 didirikan 57 tahun yang lalu pada tanggal 3 Januari 1960 dan dikukuhkan oleh Keputusan Menteri Agama No. 85 Tahun 1961 diakui bahwa BP4 adalah satu-satunya badan yang berusaha bergerak di bidang penasehatan dan pengurangan perceraian. Fungsi dan tugas BP4 tetap konsisten melaksanakan UU No. 1 Tahun 1974 tentang Perkawinan. Oleh karenanya, fungsi dan peranan BP4 sangat diperlukan masyarakat dalam mewujudkan kualitas perkawinan, termasuk bagi masyarakat di Kabupaten Minahasa Utara.

Meskipun demikian, beberapa masalah tetap muncul dalam dasawarsa terakhir menyangkut perkawinan dan rumah tangga berkembang pesat antara lain meningkatnya angka perceraiannya, kesalahan pahaman dalam keluarga

4 Tihami Sohari Sahrani, Fikih Munakahat Kajian Fikih Lengkap (Jakarta: PT Raja Grafindo Persada, 2010) h. 188.

${ }^{5}$ Ahmad Musthofa Al-Maraghiy, Tafsif AlMaraghiy jilid 5, Terjemahan K, Anshori Umar (Semarang: Toha Putra, 1988), h. 49.

6 Abdul Aziz Dahlan, Ensiklopedi Hukum Islam, Jilid V (Jakarta : PT Lehtiar Baru Van Hoeve, 1998), h. 1750. 
yang mengakibatkan pertengkaran, permasalahan ekonomi keluarga, poligami terselubung (perselingkuhan), serta kekerasan dalam berumah tangga, mewarnai dinamika problematika perkawinan.

Perceraian dalam hukum Islam adalah suatu perbuatan yang halal dan mempunyai prinsip dilarang oleh Allah swt. Namun faktanya, perceraian itu menjadi fenomena yang tidak dapat terelakkan karena maraknya konflik rumah tangga yang terjadi dalam masyarakat. Mulai dari perceraian yang disebabkan pertengkaran secara terusmenerus atau sebab lain. Oleh karena itu, Allah memberikan solusi yang sangat bijak agar menunjuk seorang hakam atau mediator yaitu juru penengah. Keberadaan mediator dalam kasus perkawinan merupakan penjabaran dari perintah Al-Quran. Dalam Al-Quran disebutkan bahwa jika ada permasalahan dalam perkawinan, maka diharuskan diangkat seorang hakam yang akan menjadi mediator. Dengan demikian, keberadaan hakam menjadi penting adanya. ${ }^{7}$

Dasar hukumnya seperti yang terdapat dalam Peraturan Menteri Agama No. 3 Tahun 1975 Pasal 28 ayat (3) menyebutkan bahwa "Pengadilan Agama dalam berusaha mendamaikan kedua belah pihak dapat meminta bantuan kepada Badan Penasehat Perkawinan, Perselisihan dan Perceraian (BP4) agar menasehati kedua suami istri tersebut untuk hidup makmur lagi dalam rumah tangga". Kemudian dalam Konsideran Munas BP4 ke-XV Tahun 2014 di Jakarta menyebutkan peran dan fungsi BP4 terhadap mediasi dalam permasalahan rumah tangga. Penulis tertarik untuk

${ }^{7}$ Ibid, h. 227

8 Suharsimi Arikunto, Prosedur Penelitian Suatu Pendekatan Praktek (Jakarta: Rineka Cipta, 1992), h. 131-152. mengetahui beberapa teknik serta keefektifan dan hambatan dalam pelaksanaan mediasi oleh BP4 pada perselisihan rumah tangga di Kabupaten Minahasa Utara.

Kemudian timbul pertanyaanpertanyaan, bagaimana praktik mediasi oleh BP4 di Kabupaten Minahasa Utara dalam menyelesaikan perselisihan rumah tangga pasca nikah?

\section{Moteode Penelitian}

Penelitian ini termasuk field reserch yang dikaji dengan menggunakan pendekatan yuridisempiris $^{8}$ dan sifatnya adalah deskriptifanalitik. Lokasi penelitian dilakukan di seluruh Kantor Urusan Agama pada Kabupaten Minahasa Utara sebagai pusat kerja BP4.

Untuk mendapatkan data yang relevan, teknik pengumpulkan data yang digunakan dalam penelitian ini adalah; (1) observasi partisipan, (2) wawancara, dan (3) dokumentasi. Dan untuk menganalisanya datanya digunakan analisis deskriptif-kualitatif. ${ }^{9}$

\section{Gambaran BP4 Kabupaten Minahasa Utara}

Badan penasehatan pembinaan dan pelestarian perkawinan (BP4) dalam penyelesaian perselisihan rumah tangga di Kabupaten Minahasa Utara terdiri 5 BP4 kecamatan. Seluruhnya merupakan organisasi profesional, mitra kerja Kementerian Agama dan institusi terkait bertujuan mempertinggi mutu perkawinan dalam mewujudkan rumah tangga yang bahagia dan sejahtera yaitu rumah tangga sakinah, mawaddah dan rahmah dengan mengembangkan Program Gerakan Rumah tangga Sakinah.

9 Lexy J. Moloeng, Metodologi Penelitian Kualitatif (Bandung: Rosda Karya, 2002), h. 112 
Karena tugasnya berkenaan dengan aspek hukum dan ritual yang sangat menyentuh kehidupan keseharian masyarakat, maka tugas dan fungsi BP4 semakin hari semakin menunjukkan peningkatan kuantitas dan kualitasnya.

Peningkatan ini tentunya mendorong BP4 sebagai pejabat yang bertanggung jawab dalam melaksanakan dan mengkoordinasikan tugas-tugas untuk bersikap dinamis, proaktif, kreatif, mandiri, aspiratif dan berorientasi pada penegakkan peraturan yang berlaku. Untuk lebih mendorong kualitas kinerja dan sumberdaya manusia, BP4 berupaya melakukan berbagai terobosan yang efektif yang intinya selain bersifat koordinatif, juga sekaligus evaluatif dalam pelaksanaan tugas-tugas. adalah:

Adapun kelima BP4 tersebut

1. BP4 Kecamatan Airmadidi

2. BP4 Kecamatan Kauditan

3. BP4 Kecamatan Dimembe

4. BP4 Kecamatan Likupang

5. BP4 Kecamatan Wori

Hasil Mediasi BP4 di Kabupaten Minahasa Utara Tahun 2017

1. Perselisihan yang disebabkan karena kesalah pahaman dalam rumah tangga hingga terjadi pertengkaran.

\begin{tabular}{|c|c|c|l|}
\hline $\begin{array}{c}\mathrm{N} \\
\mathrm{o}\end{array}$ & \multicolumn{1}{|c|}{ Nama } & Lokasi & \multicolumn{1}{|c|}{ Ket. } \\
\hline 1 & $\begin{array}{l}\text { Kel. } \\
\text { Hermanto }\end{array}$ & $\begin{array}{l}\text { BP4 } \\
\text { Airmadidi }\end{array}$ & $\begin{array}{l}\text { Dapat di } \\
\text { damaikan } \\
\text { dengan proses } \\
\text { mediasi }\end{array}$ \\
\hline 2 & $\begin{array}{l}\text { Kel. } \\
\text { Anwar bin } \\
\text { Saifudin }\end{array}$ & Airmadidi & $\begin{array}{l}\text { Dapat di } \\
\text { damaikan } \\
\text { dengan proses } \\
\text { mediasi }\end{array}$ \\
\hline
\end{tabular}

Dari tabel di atas peneliti menemukan data di lapangan bahwa,

10 Hermanto, Selaku pihak yang termediasi dalam perselisihan rumah tangga, wawancara pada tanggal 05 September 2017 terdapat dua rumah tangga tediri dari Kel. Hermanto dan Kel. Anwar bin Syaifudin dari kecamatan Airmadidi atau wilayah tugas BP4 Kecamatan Airmadidi, telah selesai di mediasi oleh BP4 Kecamatan Airmadidi dan terselesaikan dengan hasil yang cukup baik.

Berdasarkan

Wawancara dengan Hermanto selaku Pihak yang termediasi dalam perselisihan rumah tangga. tanggal 05 September 2017 pukul 11.10 WITA:

"Di dalam hati yang sebenarnya adalah tidak mau ada perselisihan dalam rumah tangga, untuk itu dengan hati yang ikhlas mendatangi BP4 di Kecamatan Airmadidi dalam upaya memohon kiranya membantu untuk menyatukan kembali rumah tangga." 10

BP4 memberikan nasihat kepada dua rumah tangga tersebut, dengan cara meminta keterangan terlebih dahulu kepada pihak masing-masing sehingga dapat mengetahui permasalahan yang menjadi penyebab perselisihan.

Kemudian

BP4 mempertemukan kepada mereka untuk mengungkapkan semua permasalahan yang menjadi kesalah pahaman antara kedua, kemudian BP4 memberikan nasehat-nasehat tentang perkawinan serta hak dan tanggung jawab sebagai anggota rumah tangga yang berdasarkan syariat islam sehingga dapat mendamaikan kepada kedua belah pihak.

2. Perselisihan yang disebabkan karena masalah ekonomi. 


\begin{tabular}{|c|l|l|l|}
\hline $\begin{array}{c}\mathrm{N} \\
\mathrm{o}\end{array}$ & \multicolumn{1}{|c|}{ Nama } & Lokasi & \multicolumn{1}{|c|}{ Ket. } \\
\hline 1 & $\begin{array}{l}\text { Kel. } \\
\text { Junaidi } \\
\text { Demobi }\end{array}$ & BP4. Wori & $\begin{array}{l}\text { Dapat di } \\
\text { damaikan } \\
\text { dengan proses } \\
\text { mediasi }\end{array}$ \\
\hline 2 & $\begin{array}{l}\text { Kel. } \\
\text { Rosmini }\end{array}$ & $\begin{array}{l}\text { BP4. } \\
\text { Likupang }\end{array}$ & $\begin{array}{l}\text { Dapat di } \\
\text { damaikan } \\
\text { dengan proses } \\
\text { mediasi }\end{array}$ \\
\hline 3 & Kel. Sarjan & $\begin{array}{l}\text { BP4. } \\
\text { Dimembe }\end{array}$ & $\begin{array}{l}\text { Dapat di } \\
\text { damaikan } \\
\text { dengan proses } \\
\text { mediasi }\end{array}$ \\
\hline 4 & Kel. Amir & $\begin{array}{l}\text { BP4 } \\
\text { Airmadidi }\end{array}$ & $\begin{array}{l}\text { Dapat di } \\
\text { damaikan } \\
\text { dengan proses } \\
\text { mediasi }\end{array}$ \\
\hline 5 & $\begin{array}{l}\text { Kel. Sofia } \\
\text { Ningsih } \\
\text { Rempi }\end{array}$ & $\begin{array}{l}\text { BP4 } \\
\text { Kauditan }\end{array}$ & $\begin{array}{l}\text { Dapat di } \\
\text { damaikan } \\
\text { dengan proses } \\
\text { mediasi }\end{array}$ \\
\hline 6 & $\begin{array}{l}\text { Kel. Mira } \\
\text { Mahmud }\end{array}$ & $\begin{array}{l}\text { BP4 } \\
\text { Kauditan } \\
\text { damat di } \\
\text { dengan proses } \\
\text { mediasi }\end{array}$ \\
\hline
\end{tabular}

Dari tabel di atas dari Bulan Januari sampai September 2017 peneliti menemukan 6 pasangan rumah tangga di mediasi terhadap perselisihan disebabkan karena masalah ekonomi,

Berdasarkan Wawancara dengan Junaidi Demobi selaku Pihak yang termediasi dalam perselisihan rumah tangga. tanggal 07 September 2017 pukul 09.18 WITA:

"Kami sering mengalami perselisihan dalam rumah tangga disebabkan kebutuhan dalam rumah tangga, dikarenakan suami yang lalai dalam memenuhi tanggug jawab memenuhi kebutuhan rumah tangga."11

Masalah ekonomi membuat enam rumah tangga terjadi perselisihan, sehingga pasangan sebagian rumah tangga berkeinginan

11 Junaidi Debobi, Selaku pihak yang termediasi dalam perselisihan rumah tangga, wawancara pada tanggal 07 September 2017. untuk bercerai, Hal tersebut dapat di mediasi BP4, BP4 menjalankan fungsinya sebagai mediator rumah tangga yang sedang mengalami masalah perkawinan dan memberikan nasihat serta berikan opsi-opsi solusi dalam menangani masalah-masalah rumah tangga, hal tersebut dapat diterima semua pasangan rumah tangga yang mengalami perselisihan disebabkan masalah ekonomi, enam rumah tangga yang berselisih dapat kembali hidup rukun dan bahagia dalam membina rumah tangga.

3. Perselisihan yang disebabkan karena perselingkuhan

\begin{tabular}{|c|c|c|c|}
\hline $\mathrm{N}$ & Nama & Lokasi & Ket. \\
\hline 1 & $\begin{array}{l}\text { Nursiah } \\
\text { Siwi }\end{array}$ & BP4 Wori & $\begin{array}{l}\text { Dapat di } \\
\text { damaikan } \\
\text { dengan proses } \\
\text { mediasi }\end{array}$ \\
\hline 2 & $\begin{array}{l}\text { Amran Bin } \\
\text { Saleh }\end{array}$ & BP4 Wori & $\begin{array}{l}\text { Dapat di } \\
\text { damaikan } \\
\text { dengan proses } \\
\text { mediasi }\end{array}$ \\
\hline 3 & Maman & $\begin{array}{l}\text { BP4 } \\
\text { Dimembe }\end{array}$ & $\begin{array}{l}\text { Dapat di } \\
\text { damaikan } \\
\text { dengan proses } \\
\text { mediasi }\end{array}$ \\
\hline 4 & $\begin{array}{c}\text { Kel.Ismet } \\
\text { Bilah } \\
\text { ima }\end{array}$ & $\begin{array}{l}\text { BP4. } \\
\text { Kauditan }\end{array}$ & $\begin{array}{l}\text { Dapat di } \\
\text { damaikan } \\
\text { dengan proses } \\
\text { mediasi }\end{array}$ \\
\hline 5 & $\begin{array}{ll}\text { Kel. } & \\
& \text { Enda } \\
\text { ng } \\
\text { Tanio }\end{array}$ & $\begin{array}{l}\text { BP4 } \\
\text { Kauditan }\end{array}$ & $\begin{array}{l}\text { Dapat di } \\
\text { damaikan } \\
\text { dengan proses } \\
\text { mediasi }\end{array}$ \\
\hline 6 & $\begin{array}{l}\text { Kel. } \\
\qquad \begin{array}{l}\text { Rah } \\
\text { mat }\end{array}\end{array}$ & $\begin{array}{l}\text { BP4 } \\
\text { Kauditan }\end{array}$ & $\begin{array}{l}\text { Dapat di } \\
\text { damaikan } \\
\text { dengan proses } \\
\text { mediasi }\end{array}$ \\
\hline
\end{tabular}

Berdasarkan Wawancara dengan Rahmad/Susan selaku Pihak yang termediasi dalam perselisihan 
rumah tangga. tanggal 30 Agustus 2017 pukul 12.07 WITA:

"Dalam rumah tangga kami pernah terjadi perselisihan yang disebabkan orang ketiga, maksudnya ada yang menggangu kedamaian dalam rumah tangga yaitu perempuan yang menyukai suami saya, ini yang menyebabkan perselisihan tetapi adanya BP4 yang membantu dalam upaya memediasi sehingga dapat terselesaikan dan kami hidup rukun dan damai kembali."12

Dalam perkembangan ilmu dan teknologi pada zaman modern, kehidupan bermasyarakat dalam hidup bersosial, seringkali menyalah gunakan konsep pergaulan dalam segi negatif dan mengakibatkan perselingkuhan. Ini yang menyebabkan keretakan dalam rumah tangga. Peneliti menemukan data di Minahasa Utara dari Bulan Januari hingga bulan September 2017 terdapat 6 (Enam) pasangan keluarga yang mengalami perselisihan yang disebabkan terjadinya perselingkuhan.

Adanya laporan dari pihak ke BP4, maka BP4 memanggil pihakpihak yang berselisih untuk dimintai keterangan terhadap duduk persoalan yang mengakibatkan perselisihan, karena di lain pihan bersikeras untuk tidak mau di mediasi maka pihak BP4 bekerja sama dengan tokoh-tokoh masyarakat dan tokoh agama guna mendamaikan rumah tangga yang berselisih.

Dengan adanya tanggung jawab serta usaha BP4 maka enam pasang

12 Rahmad, Selaku pihak yang termediasi dalam perselisihan rumah tangga, wawancara pada tanggal 30 Agustus 2017. rumah tangga dapat di damaikan dan dapat diselesaikan dengan baik tanpa melanjutkan ke jenjang perceraian di Pengadilan Agama.

4. Perselisihan yang disebabkan karena suami meninggalkan rumah tangga dan tidak memberikan nafkah lahir batin.

\begin{tabular}{|c|c|l|l|}
\hline $\begin{array}{l}\mathrm{N} \\
\mathrm{o}\end{array}$ & Nama & Lokasi & \multicolumn{1}{|c|}{ Ket. } \\
\hline 1 & Kel. Yenni & $\begin{array}{l}\text { BP4 Kec. } \\
\text { Likupang }\end{array}$ & $\begin{array}{l}\text { Dapat di } \\
\text { damaikan } \\
\text { dengan proses } \\
\text { mediasi }\end{array}$ \\
\hline 2 & $\begin{array}{l}\text { Kel. Jafar/ } \\
\text { Arianti }\end{array}$ & $\begin{array}{l}\text { BP4 Kec. } \\
\text { Kauditan }\end{array}$ & $\begin{array}{l}\text { Dapat di } \\
\text { damaikan } \\
\text { dengan proses } \\
\text { mediasi }\end{array}$ \\
\hline 3 & $\begin{array}{l}\text { Kel. Indan } \\
\text { Meilani }\end{array}$ & $\begin{array}{l}\text { BP4 } \\
\text { Airmadidi }\end{array}$ & $\begin{array}{l}\text { Masih dalam } \\
\text { proses mediasi }\end{array}$ \\
\hline
\end{tabular}

Dari tabel diatas peneliti menemukan data di BP4 kecamatan pada Kabupaten Minahasa Utara. Bahwa terjadi perselisihan dalam rumah tangga seringkali disebabkan lalainya kepala Rumah tangga tidak memahami tanggung jawab sebagai kepala rumah tangga. Hal tersebut adanya laporan pihak kepada BP4 dikarenakan kepala rumah tangga tidak memberikan nafkah Lahir maupun batin.

Berdasarkan Wawancara dengan Arianti selaku Pihak yang termediasi dalam perselisihan rumah tangga. tanggal 08 September 2017 pukul 13.07 WITA:

"kami sebagai pihak meloporkan ke BP4 untuk meminta dalam upaya memediasi, sehingga dapat jalan keluarnya untuk penyelesaian masalah kami."13

Adanya laporan ke BP4, maka BP4 memanggil yang bersangakutan

13 Arianti, Selaku pihak yang termediasi dalam perselisihan rumah tangga, wawancara pada tanggal 08 September 2017. 
untuk dimintai keterangan terhadap permasalahan-permasalahan yang menjadikan perselisihan tersebut. Dalam usaha-usaha BP4 untuk di pertemukan serta di berikan nasehati atas dasar Tanggung jawab sebagai kepala rumah tangga serta pemahaman agama yang jelas dalam perkawinan.

Dalam penanganan BP4 dalam memediasi perselisihan rumah tangga. Keluarga Indah Melani masih dalam proses memediasi, disebabkan keberadaan kepala rumah tangga di luar daerah sehingga BP4 mengalami kendala atau hambatan adanya keberadaan pihak di luar daerah.

Hal tersebut dapat di mediasi oleh BP4, sehingga perselisihan dalam keluarga yang disebabkan oleh lalainya kepala rumah tangga memberikan nafkah lahir maupun batin dapat terselesaikan, dan dapat kembali menjadi rumah tangga yang utuh serta hidup dalam rumah tangga yang harmonis.

5. Perselisihan yang disebabkan karena salah satu pihak melakukan kekerasan dalam rumah tangga.

\begin{tabular}{|c|c|c|l|}
\hline $\begin{array}{c}\text { N } \\
\text { o }\end{array}$ & \multicolumn{1}{|c|}{ Nama } & Lokasi & \multicolumn{1}{|c|}{ Ket. } \\
\hline 1 & $\begin{array}{l}\text { Kel. Rizal } \\
\text { amir }\end{array}$ & $\begin{array}{l}\text { BP4 } \\
\text { Airmadidi }\end{array}$ & $\begin{array}{l}\text { Dapat di } \\
\text { damaikan } \\
\text { dengan proses } \\
\text { mediasi }\end{array}$ \\
\hline 2 & $\begin{array}{l}\text { Kel. Aditya } \\
\text { hasan }\end{array}$ & $\begin{array}{l}\text { BP4 } \\
\text { Airmadidi }\end{array}$ & $\begin{array}{l}\text { Dapat di } \\
\text { damaikan } \\
\text { dengan proses } \\
\text { mediasi }\end{array}$ \\
\hline
\end{tabular}

Setiap rumah tangga dalam membangun kehidupan dalam rumah tangga seringkali muncul perselisihan adanya kekerasan dalam rumah tangga. Hal tersebut adanya laporan dari bulan Januari hingga September 2017 ke BP4.

Berdasarkan Wawancara dengan Rizal Amir selaku Pihak yang termediasi dalam perselisihan rumah tangga. tanggal 13 September 2017 pukul 10.53 WITA:

"Semua rumah tangga tidak menginginkan ada perselisihan yang disebabkan kekerasan dalam rumahtangga hingga perceraian, masalah ini terjadi kepada kami, maka saya melaporkan ke BP4 untu memediasi dalam upaya menyelesaikan perselisihan yang menimpa pada rumah tangga kami."14

Data yang diperoleh peneliti, ada 2 (dua) rumah tangga yang melapor ke BP4. Dengan adanya laporan maka BP4 memanggil kepada yang bersangkutan atau pihak-pihak yang berselisih untuk di mintai keterangan dalam rangka memediasi untuk memperbaiki dalam kehidupan rumah tangga mereka.

Dengan adanya mediasi tesebut, maka perselisihan dalam rumah tangga yang disebabkan oleh kekerasan dalam rumah tangga dapat diselesaikan. dan setiap pihak mau memahami atas kekurangankekurangan yang menyebabkan perselisihan.

6. Perselisihan yang disebabkan karena campur tangan orang tua dalam rumah tangga anak.

\begin{tabular}{|c|l|l|l|}
\hline $\mathrm{N}$ & \multicolumn{1}{|c|}{ Nama } & \multicolumn{1}{c|}{ Lokasi } & \multicolumn{1}{c|}{ Ket. } \\
$\mathrm{o}$ & & BP4 Kec. & $\begin{array}{l}\text { Dapat di } \\
\text { damaikan } \\
\text { dengan proses } \\
\text { mediasi }\end{array}$ \\
\hline
\end{tabular}

14 Rizal Amir, Selaku pihak yang termediasi dalam perselisihan rumah tangga, wawancara pada tanggal 13 September 2017. 
Berdasarkan Wawancara dengan Indriani Paputungan selaku Pihak yang termediasi dalam perselisihan rumah tangga. tanggal 28 September 2017 pukul 11.38 WITA:

"saya menginginkan supaya masalah yang terjadi pada rumah tangga kami tidak ada yang ikut campur tangan dari pihak lain, sehingga tidak memperkeruh perselisihan dalam rumah tangga. Intinya kami tidak menginginkan perselisihan sehingga menyebabkan perceraian."15

Dari data wawancara di atas, perselisihan disebabkan karena campur tangan orang tua dalam rumah tangga sering terjadi, ini terjadi pada rumah tangga Indriani Paputungan yang berdomisili di kecamatan Likupang. Hal tersebut dapat ditangani pihak BP4 atas dasar laporan salah satu pihak, maka upaya BP4 memediasi guna mendamaikan serta menasehati tentang peran dan hak serta tanggung jawab setiap anggota rumah tangga.

\section{Teknik-teknik BP4 Dalam Memediasi Terhadap Penyelesaian Perselisihan Rumah Tangga di Kabupaten Minahasa Utara}

Peranan BP-4 dalam mengurangi terjadinya perceraian hanya bersifat membantu menyelesaikan masalah yang dihadapi oleh pasangan suami istri yang berselisih supaya damai. Badan penasehat yang ada di Minahasa Utara mempunyai beberapa cara atau teknikteknik dalam memecahkan permasalahan yang dihadapi oleh pasangan suami istri di antaranya yaitu Pertama Petugas BP4 menyambut dengan baik klien yang datang ke BP4 dengan keperluan mediasi, berupa

15 Indriani Paputungan, Selaku pihak yang termediasi dalam perselisihan rumah diskusi atau wawancara yang dilakukan oleh Petugas BP-4 denga pihak yang berselisih. Kedua BP4 bekerja sama sektoral dengan Pemerintah, Tokoh Masyarakat serta tokoh Agama guna memediasi perselisihan dalam rumah tangga, Ketiga BP4 mempertemukan rumah tangga yang berselisih dalam sidang, Dengan demikian dapat diketahui permasalahannya, setelah itu BP-4 akan memberikan solusi dari penyelesaian permasalahan tersebut. Untuk lebih lanjutnya BP-4 menyerahkan keputusan tersebut kepada pasangan suami istri yang berselisih. Bp-4 hanya menyarankan kepada pasanga suami istri untuk terlebih dahulu diselesaikan secara kekeluargaan yaitu meminta pendapat keluarga.

Berdasarkan observasi yang dilakukan oleh peneliti pada tanggal 12 September 2017 pukul 09.30 WITA, peran BP4 dalam mencegah terjadinya perselisihan sampai hingga perceraian adalah sebagai berikut:

Usaha yang dilakukan BP4 apabila ada masyarakat Kabupaten Minahasa Utara yang datang ke BP4 untuk melakukan pengaduan tentang perselisihan dalam rumah tangga yang akan mengakibatkan perceraian adalah sebagai berikut:

1. Petugas BP4 menyambut dengan baik klien yang datang ke BP4 dengan keperluan mediasi.

2. BP4 bekerja sama dengan Pemerintah, Tokoh Masyarakat serta tokoh Agama guna memediasi perselisihan dalam rumah tangga.

3. BP4 mempertemukan rumah tangga yang berselisih dalam sidang.

Sedangkan metode atau teknik yang digunakan BP-4 dalam melakukan pembinaan dari permasalahan dalam rumah tangga di atas untuk

tangga, Wawancara pada tanggal 28 September 2017. 
mengantisipasi tingkat perceraian di Kabupaten Minahasa Utara sebagai berikut :

1. Metode informatif, yang bersifat memberikan penerangan atau informasi. Dengan melakukan metode ini kepada keluarga/masyarakat yang sedang mengalami masalah untuk memberikan penyuluhan, nasehatnasehat, dan solusi agar mampu menyelesaikan masalah yang merka hadapi.

2. Metode sugesti dan persuasif, yaitu cara mempengaruhi klien agar bersedia mengikuti nasehat yang diberikan.

3. Metode edukatif, yaitu cara pemberian nasehat yang bersifat mendidik.

4. Metode diskusi, yaitu mengarah pada pemecahan masalah dengan menjelaskan problem yang dihadapi klien.

5. Metode ceramah, yang dimaksud adalah cara menyampaikan sebuah materi pelajaran dengan cara peraturan lisan kepada semua pihak. ${ }^{16}$

Konsepsinya adalah, bahwa cara yang dilakukan BP4 dalam memediasi terhadap perselisihan dalam rumah tangga adalah memberikan nasihat kepada pasangan tersebut disesuaikan dengan permasalahan yang menyebabkan terjadinya Perselisihan.

Dalam mencegah terjadinya perselisihan dalam rumah tangga, BP4 mempertemukan pasangan yang berselisih paham dalam rumah tangga, rumah tangga tersebut dipertemukan dalam sebuah forum guna mengetahui duduk perkara yang sebenarnya, dan BP4 memberikan nasihat-nasihat. Pemberian nasihat disesuaikan dengan masalah yang menyebabkan perselisihan dalam rumah tangga.

Apabila nasihat tersebut dapat diterima dengan baik, maka mereka akan berdamai, hidup bersama lagi dalam satu rumah. Jika nasihat tersebut tidak dapat dilaksanakan, maka karena BP4 hanya sebagai mediator, BP4 tidak berani memutuskan perselisihan rumah tangga mereka, BP4 menyerahkan keputusan kepada mereka. Jika perselisihan yang tidak bisa di mediasi dalam menyerlesaikan masalah rumah tangga dan perceraian yang mereka kehendaki, maka tugas BP4 adalah membuatkan surat pengantar untuk mengajukan perceraian di Pengadilan Agama.

BP4 sebagai mitra kerja Kementerian Agama mempunyai tujuan untuk mewujudkan rumah tangga sakinah berdasarkan Islam. BP4 adalah badan yang berusaha di bidang penasihatan perkawinan dan pengurangan perceraian. Peran BP4 dalam mencegah terjadinya perselisihan yang mengakibatkan perceraian adalah menjadi mediator perkawinan, harapannya BP4 dapat menurunkan tingkat perselisihan pada perceraian di Kabupaten Minahasa Utara. Hal itu sesui dengan teori Biddle dan Thomas, peran adalah serangkaian rumusan yang membatasi perilaku-perilaku yang diharapkan dari pemegang kedudukan tertentu.

Jika dihubungkan dengan Pokokpokok Program Kerja yang tertuang dalam Keputusan Musyawarah Nasional BP4 ke XV tahun 2014 Nomor : 260/2P/BP4/VIII/2014, Peran BP4 dalam mencegah terjadinya perselisihan rumah tangga yang mengakibatkan perceraian sudah sesuai dengan Pokok-
16 Ismed Djaelami, Selaku tokoh Masayakat juga tokoh Agama, Wawancara pada tanggal 28 September 2017 
Pokok Program Kerja khususnya dalam bidang mediasi perkawinan.

Dikatakan sudah sesuai, karena dalam mencegah terjadinya perceraian BP4 benar-benar bertindak sebagai mediator yang baik. BP4 berusaha memberikan nasihat yang dapat menenangkan hati, nasihat tersebut disampaikan dengan cara yang halus, meskipun perselisihan dalam rumah tangga bersikeras untuk tetap bercerai, namun BP4 dengan sabar terus memberi masukan kepada mereka.

Sebagai mediator yang baik, BP4 bersifat netral, tidak memihak antara pihak yang satu dengan pihak yang lain. BP4 memberikan kesempatan yang sama kepada rumah tangga untuk mengungkapkan pendapat dan juga untuk mendengarkan pendapat dari pihak lain.

Apabila pihak rumah tangga yang berselisih paham tetap besikeras terus berusaha agar permohonan perceraiannya dapat dikabulkan oleh BP4, BP4 juga terus berusaha untuk mendamaikan mereka lagi. BP4 merasa bertanggung jawab sebagai mediator dalam perkawinan, sehingga BP4 mempersulit terjadinya perceraian dengan memberikan waktu satu bulan untuk melaksanakan nasihat yang diberikan BP4.

BP4 hanya menjadi fasilitator yang membantu para pihak dalam meluruskan perbedaan-perbedaan pandangan, tidak memutuskan suatu perkara. mediator tidak berwenang memutuskan sengketa para pihak, melainkan hanya membantu para pihak dalam menyelesaikan persoalanpersoalan, dan itu pun jika para pihak menguasakan kepadanya untuk membantu penyelesaian sengketa.

Jadi antara teori dan praktek yang dilaksanakan oleh BP4 sudah sesuai. Meskipun hasil yang dicapai kurang maksimal, terbukti dengan pasangan yang mendatangi BP4 pada tahun 2017 adalah 20 orang dan yang bisa didamaikan kembali hanya 1 orang masih dalam proses Mediasi, namun usaha yang dilakukan oleh BP4 sudah sesuai dengan Pokok-Pokok Program Kerja.

\section{Efektifitas Mediasi BP4 di Kabupaten Minahasa Utara}

Keberhasilan mediasi ini juga didukung dengan kewibawaan para mediator BP4 di Kabupaten Minahasa Utara, pada umumnya para pihak telah mengenal siapa mediator, baik dari segi ilmu, sifat dan keseharian mereka yang membuat para pihak merasa segan dan patuh terhadap mediator mereka sehingga apa yang mediator sarankan mereka terima sebagai suatu saran yang paling baik bagi keduabelah pihak dan masyarakat yang dapat membawa kemashlahatan.

Kepandaian mediator di Kabupaten Minahasa Utara dalam mengolah pikiran para pihak juga menjadi faktor penunjang, pada umumnya mediator telah mengenal dan memahami sifat dan karakter para pihak, hal ini sangatlah perlu dalam pelaksanaan mediasi sehingga mediator dapat menentukan langkah apa yang harus diambil dalam menyelesaikan masalah kepada para pihak.

Berdasarkan Wawancara dengan Saman Bina selaku petugas BP4 yang menangani salah satu perselisihan dalam rumah tangga tanggal 19 September 2017 pukul 11.17 WITA:

"Selama kami melaksanakan mediasi para pihak yang melaporkan permasalahan yang terjadi dalam rumah tangganya, kami dapat menyelesaikan dengan baik serta dapat rukun kembali hidup dalam keluarga yang harmonis atas dasar saling 
memahami kekurangan dan kelebihan dalam setiap anggota keluarga"17

Sama halnya hasil wawancara dari bapak Bambang Sutrisno selaku petugas BP4 yang menangani salah satu perselisihan dalam rumah tangga di Kecamatan Kauditan. tanggal 23 Agustus 2017 pukul 14.06 WITA:

"Selama kami melaksanakan proses mediasi terhadap perselisihan dalam rumah tangga cukup berhasil, ini di sebabkan adanya para pihak beriktikad baik untuk berdamai atau rukun kembali dalam membangun rumah tangga."18

Proses penyelesaian mediasi BP4 di Kabupaten Minahasa Utara adalah proses penyelesaian yang relatif cepat, sederhana dan mudah, sehingga keadan membuat para pihak yang melakukan mediasi menjadi nyaman dan leluasa dalam menyampaikan pendapatnya.

Para mediator yang bertugas menawarkan solusi. Sehingga usaha dalam mendamaikan para pihak yang berperkara juga dianggap sebagai suatu tugas dan kewajiban yang harus diselesaikan demi menjaga keharmonisan dalam rumah tangga.

Mediasi yang dilakukan para mediator di Kabupaten Minahasa Utara adalah mediasi interaktif dimana mediator lebih berperan aktif dari pada para pihak, hal ini menunjukan bahwa ada itikad besar dalam diri mediator untuk menyelesaikan perselisihan dengan jalan musyawarah dan perdamaian.

Dalam proses mediasi memang seharusnya mediator lebih banyak berperan aktif dari pada para pihak dalam mengemukakan pendapat, sehingga mediator benar-benar bertugas sebagai pihak penengah dari para pihak bukan sebagai pihak

17 Saman Bina, S.Ag. Selaku Petugas BP4 Kecamatan Wori, wawancara pada tanggal 19 September 2017. pendukung. hal ini juga menunjukan bahwa mediator harus punya kepandaian dan kepiawaian dalam menghadapi suatu perkara yang dihadapkan kepadanya.

Suatu permasalahan rumah tangga yang terjadi dilingkup masyarakat merupakan suatu konflik yang harus ditangani, karena konflik tidak akan selesai dengan sendirinya tanpa ada usaha dan itikad untuk menyelesaikannya, penyelesaian masalah merupakan suatu kebutuhan bukan kewajiban, karena konflik dapat mengganggu kenyamanan dan keharmonisan dalam masyarakat. maka dituntut adanya suatu pemikiran yang terbuka serta diperlukan suatu penafsiran yang lebih dalam membaca suatu fenomena yang terjadi di dalam kehidupan sosial masyarakat.

Sama halnya dengan peran mediator yang telah disebutkan diatas, selain itu mediator di Kabupaten Minahasa Utara juga berperan dalam memberikan pendidikan dan bimbingan kepada para pihak yang berselisih, terutama jika para pihak tidak dalam posisi yang sama seperti pihak pertama memiliki tingkat pendidikan dan pengetahuan yang lebih luas jika dibandingkan dengan pihak kedua yang tingkat pengetahuannya lebih rendah, sehingga perlu adanya semacam pendidikan atau paling tidak pengertian mengenai duduk perkaranya, sehingga kedua belah pihak dapat mengerti dengan jelas mengenai permasalahan atau perkaranya. Jadi seorang mediator tidak hanya melakukan pendamaian saja, melainkan juga ada pembinaan di dalamnya.

Pemecahan masalah yang digunakan oleh mediator di Kabupaten Minahasa Utara dalam memediasi para

18 Bambang Sutrisno, S.Ag, M.AP. Selaku Petugas BP4 Kecamatan Kauditan, Wawancara pada tanggal 23 Agustus 2017. 
pihak yang berselisih merupakan salah satu cara yang bertujuan untuk mendapatkan hasil yang dapat diterima oleh pihak-pihak yang berselisih, dari kasus yang mereka hadapi.

Demikian jika digabungkan dengan definisi efektivitas yang menyatakan bahwa efektivitas diartikan sebagai tingkat keberhasilan yang dapat dicapai dari suatu cara atau usaha tertentu sesuai dengan tujuan yang hendak dicapai, sejauh mana suatu ukuran dan target yang telah tercapai, maka efektivitas mediasi dapat diukur dari banyaknya perselisihan

Dalam penyelesaian BP4 dalam memediasi perselisiahan dalam rumah tangga di Kabupaten Minahasa Utara cukup berhasil, ini di sebabkan adanya peran mediator BP4 serta para pihak yang mempunyai iktikad baik dalam penyelesaian perselisihan yang tidak menginginkan perselisian dalam rumah tangga hingga perceraian. Hasil temuaan peneliti di Kabupaten Minahasa Utara sebagian besar pihak yang melaporkan perselisihan dalam rumah tangganya ke BP4 dapat dimediasi.

Keberhasilan mediasi ini juga didukung dengan kewibawaan para mediator BP4 di Kabupaten Minahasa Utara, pada umumnya para pihak telah mengenal siapa mediator, baik dari segi ilmu, sifat dan keseharian mereka yang membuat para pihak merasa segan dan patuh terhadap mediator mereka sehingga apa yang mediator sarankan mereka terima sebagai suatu saran yang paling baik bagi keduabelah pihak dan masyarakat yang dapat membawa kemashlahatan.

Tingkat keefektifan mediasi di BP4 dapat ditentukan oleh beberapa sebab antara lain:

1. Kepandaian mediator dalam membantu memecahkan masalah sehingga permasalahan dapat selesai meski hanya dengan mediasi tanpa harus ke pengadilan.
2. Itikad baik para pihak yang mendorong untuk menyelesaikan masalah secara kerumah tanggaan yang juga didorong oleh faktorfaktor lain, sehingga permasalahan dapat diselesaikan dengan baik melalui jalur mediasi.

Model mediasi yang digunakan di BP4 juga memiliki pengaruh yang cukup besar bagi tingkat keberhasilan dari proses mediasi tersebut. Model mediasi yang dilakukan lebih pada model penyelesaian, hal tersebut karena didalam mediasi yang dilakukan di BP4 memiliki ciri- ciri sebagai berikut:

1. Mediasi dilakukan guna mendekatkan perbedaan pendapat atas suatu kesepakatan.

2. Mediator hanya terfokus pada permasalahan atau posisi yang dinyatakan para pihak.

3. Fungsi mediator adalah menentukan posisi para pihak dan melakukan berbagai pendekatan untuk mendorong para pihak mencapai titik kompromi.

4. Mediator adalah orang yang mempunyai keahlian dalam proses atau teknik mediasi.

\section{Penutup}

Berdasarkan hasil penelitian dan pembahasan, dapat diambil beberapa kesimpulan sebagai berikut:

1. Faktor penyebab terjadinya perselisihan rumah tangga di Minahasa Utara.

a. Perselisihan yang disebabkan karena kesalah pahaman dalam rumah tangga hingga terjadi pertengkaran.

b. Perselisihan yang disebabkan karena masalah ekonomi

c. Perselisihan yang disebabkan karena perselingkuhan

d. Perselisihan yang disebabkan karena suami meninggalkan rumah tangga dan tidak memberikan nafkah lahir batin. 
e. Perselisihan yang disebabkan karena salah satu pihak melakukan kekerasan dalam rumah tangga.

f. Perselisihan yang disebabkan karena campur tangan orang tua dalam rumah tangga anak.

2. Teknik-teknik BP4 dalam memediasi terhadap penyelesaian perselisihan keluarga di Kabupaten Minahasa Utara

a. Petugas BP4 menyambut dengan baik klien yang datang ke BP4 untuk keperluan mediasi.

Pada dasarnya petugas BP4 menyambut atas iktikad baik setiap pihak dalam menyelesaikan perselisihan dalam rumah tangga, ini juga sebagai tugas dan tanggung jawab para petugas BP4 dalam memediasi perselisihan dalam rumah tangga.

b. BP4 bekerja sama dengan Pemerintah, Tokoh Masyarakat serta tokoh Agama guna memediasi perselisihan dalam rumah tangga.

Adanya kerja sama sektoral dengan Tokoh Pemerintah, Tokoh Masyarakat dan Tokoh Agama mempunyai peran sangat penting sehingga pihak yang berselisih dapat memahami dengan betul serta patuh dalam melaksanakan hasil keputusan dalam proses mediasi.

c. BP4 mempertemukan rumah tangga yang berselisih dalam sidang.

Peran BP4 dalam mencegah terjadinya Perselisihan dalam keluarga adalah dengan mengadakan sidang semi formal diikuti petugas BP4 sebagai mediator, pihak yang berselisih, dan saksi-saksi serta tokoh- tokoh masyarakat dan pemerintah atas dasar laporan

Teknik atau metode yang sering di lakukan BP4 dalam proses mediasi perselisihan dalam rumah tangga di Kabupaten Minahasa Uatara antara lain sebagai berikut:

a. Metode informatif, yang bersifat memberikan penerangan atau informasi. Dengan melakukan metode ini kepada keluarga/masyarakat yang sedang mengalami masalah untuk memberikan penyuluhan, nasehat-nasehat, dan solusi agar mampu menyelesaikan masalah yang merka hadapi.

b. Metode sugesti dan persuasif, yaitu cara mempengaruhi klien agar bersedia mengikuti nasehat yang diberikan.

c. Metode edukatif, yaitu cara pemberian nasehat yang bersifat mendidik.

d. Metode diskusi, yaitu mengarah pada pemecahan masalah dengan menjelaskan problem yang dihadapi klien.

e. Metode ceramah, yang dimaksud adalah cara menyampaikan sebuah materi pelajaran dengan cara peraturan lisan kepada semua pihak

3. Keefektifan dalam Mediasi pasca nikah yang diterapkan pada BP4 di Kabupaten Minahasa Utara

a. Kemampuan para pihak mediator terhadap penyelesaian perselisihan dalam rumah tangga.

Dalam mediasi BP4 di Kabupaten Minahasa utara cukup berhasil, dan dapat terselesaikan dalam mediasi di BP4 dengan baik. ini di sebabkan kepandaian mediator dalam membantu memecahkan masalah, sehingga permasalahan dapat selesai meski hanya 
dengan mediasi tanpa harus ke pengadilan.

b. Para pihak mempunyai iktikad baik dalam menyelesaikan perselisihan dalam rumah tangganya dalam mediasi BP4

Adanya iktikad baik para pihak yang mendorong untuk menyelesaikan masalah secara mediasi di BP4, sehingga permasalahan dapat diselesaikan dengan baik melalui jalur mediasi di BP4.

\section{DAFTAR PUSTAKA}

Buku:

Ali, Zainuddin., Hukum Perdata Islam di Indonesia, Jakarta: Sinar Grafika, 2006

Al-Maraghiy, Ahmad Musthofa., Tafsif AlMaraghiy, Jilid 5, Terjemahan K, Anshori Umar, Semarang: Toha Putra, 1988

Arikunto, Suharsimi. Prosedur Penelitian Suatu Pendekatan Praktek, Jakarta: Rineka Cipta, 1992

Basir, Ahmad Azhar., Hukum Perkawinan Islam, Yogyakarta: UII Press, 2007

Dahlan, Abdul Aziz., Ensiklopedi Hukum Islam, Jilid V, Jakarta: PT Lehtiar Baru Van Hoeve, 1998

Moloeng, Lexy J., Metodologi Penelitian Kualitatif, Bandung: Rosda Karya, 2002

Rajafi, Ahmad., Nalar Hukum Keluarga Islam di Indonesia, Yogyakarta: Istana Publishing, 2015

------, "Sejarah Pembentukan dan Pembaruan Hukum Keluarga Islam di Nusantara", Aqlam: Journal of Islam and Plurality, Vol. 2, No. 1, Desember 2017
, The Renewal Movement of Islamic Family Law In Indonesia (Politics of Islamic Law from Old Order until Reformation), Proceeding, 1st Biennial Conference on Sharia and Social Studies, Fakultas Syari'ah UIN Padang, 2017

Sahrani, Tihami Sohari., Fikih Munakahat Kajian Fikih Lengkap, Jakarta: PT Raja Grafindo Persada, 2010

Yanggo, Chuzaemah T., dan Anshari, Hafiz., Problematika Hukum Islam Kontemporer, Cet. IV, Jakarta: Pustaka Firdaus, 2002.

\section{Wawancara:}

Hermanto, Selaku pihak yang termediasi dalam perselisihan rumah tangga, wawancara pada tanggal 05 September 2017

Junaidi Debobi, Selaku pihak yang termediasi dalam perselisihan rumah tangga, wawancara pada tanggal 07 September 2017.

Rahmad, Selaku pihak yang termediasi dalam perselisihan rumah tangga, wawancara pada tanggal 30 Agustus 2017.

Arianti, Selaku pihak yang termediasi dalam perselisihan rumah tangga, wawancara pada tanggal 08 September 2017.

Rizal Amir, Selaku pihak yang termediasi dalam perselisihan rumah tangga, wawancara pada tanggal 13 September 2017.

Indriani Paputungan, Selaku pihak yang termediasi dalam perselisihan rumah tangga, Wawancara pada tanggal 28 September 2017.

Ismed Djaelami, Selaku tokoh Masayakat juga tokoh Agama, Wawancara pada tanggal 28 September 2017 
Saman Bina, S.Ag. Selaku Petugas BP4 Kecamatan Wori, wawancara pada tanggal 19 September 2017.

Bambang Sutrisno, S.Ag, M.AP. Selaku Petugas BP4 Kecamatan Kauditan, Wawancara pada tanggal 23 Agustus 2017. 